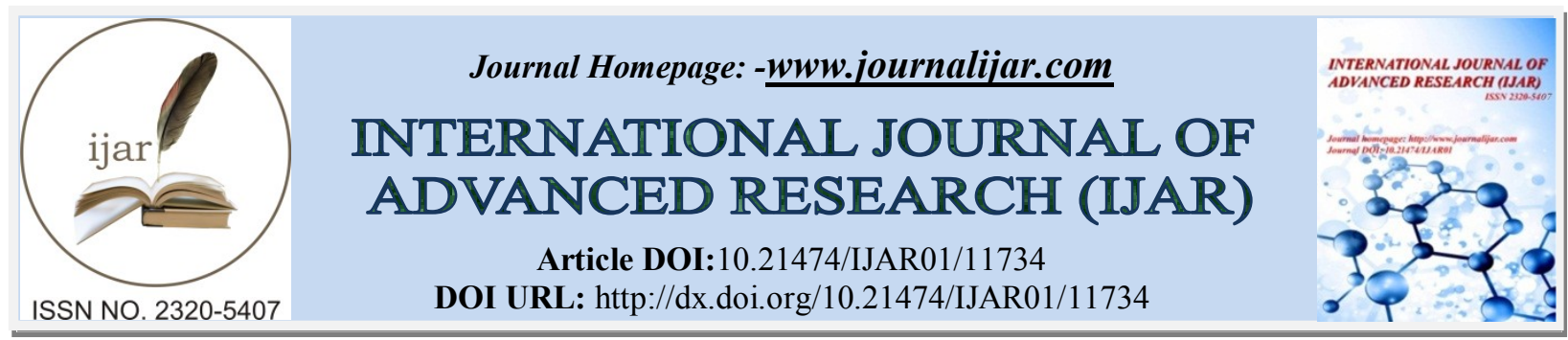

RESEARCH ARTICLE

\title{
A STUDY TO ASSESS KNOWLEDGE ON TUBERCULOSIS SPREAD IN PATIENTS ATTENDING OUTPATIENT DEPARTMENT IN A TERTIARY CARE HOSPITAL IN NALGONDA REGION
}

Dr. V. Anusha

Resident, Department of Pulmonary Medicine, Kamineni Institute of Medical Sciences, Narketpally.

\section{Manuscript Info}

Manuscript History

Received: 20 July 2020

Final Accepted: 24 August 2020

Published: September 2020
(..........................

\section{Abstract}

Introduction: India contributes one fourth of total Tuberculosis burden in the world .Poor awareness among public and negligence towards its prevention and control are cause of this widespread.

Methodology: 300 people were selected among all the patients attending pulmonary medicine department after considering inclusion and exclusion criteria .

Results: There was poor knowledge about the cause, spread of tuberculosis and disposal of sputum .Association between knowledge and age and education was observed.

Conclusion: By increasing health education and educational level the awareness about the spread and prevention can be achieved.

Copy Right, IJAR, 2020,. All rights reserved.

\section{Introduction:-}

Tuberculosis ( TB) is an ancient infection that has plagued humans throughout and appears to be as old as humanity itself .Even now it is a significant and major public health emergency worldwide and one of the top ten causes of death. Globally, 10.4 million new TB cases and 1.7 million TB-related deaths are estimated to occur each year .India has the largest number of tuberculosis patients and contributes to one fourth of total TB burden in the world . According to the global TB report of TB burden India ranks $1^{\text {st }}$ followed by Indonesia and China ${ }^{1}$.It is estimated that about $40 \%$ of the Indian population is infected with TB bacteria majority whom have latent TB .Knowledge about TB is a precursor to effective TB control .Gaps in knowledge however ,surround transmission ,prevention and the relationship between HIV/AIDS and TB. Poor understanding which is augmented by false beliefs delays health seeking behaviour and further compromises the health of patients and presents ample time for the spread of infection to healthy population ${ }^{2,3}$.Negligence of the patients and health workers towards the prevention and control of the disease leads to its widespread ${ }^{4,5}$. Many organizations and programs are conducted and funded by government of India with a goal to eradicate TB but have failed to educate people. Hence, the study was done to access the knowledge of the patients coming with respiratory problem so that health education can be increased to bring awareness among patients and prevent the disease.

\section{Methodology:-}

The study is a cross sectional study conducted at an outpatient department in a tertiary care hospital in Nalgonda . This was conducted among all the patients attending the department of pulmonary medicine who were willing to participate in the study. There were 200 people selected based on the inclusion and exclusion criteria to participate in the study. 


\section{Inclusion criteria:}

All those more than 18 years of age attending the pulmonology outpatient department and willing to participate in the study

\section{Exclusion criteria:}

Age less than 18 years, those not willing to participate in the study, serious and hemodynamically unstable patients were excluded . Patients with on going tubercular therapy and their family members were excluded to reduce bias.

The questionnaire consisted of 15 questions about the knowledge of tuberculosis and the spread of the disease and those who answered correctly for 7 questions were considered to have good knowledge and less than that were considered to have poor knowledge .

The knowledge about the tuberculosis was accessed among the participants through a pretested semi-structured questionnaire. The study was conducted from august 2018 to December 2019.

\section{Materials:-}

The materials used in this study included a questionnaire which consisted of 15 questions about the knowledge of tuberculosis and the spread of the disease .

\section{Results:-}

Out of 300 participants , 192 (64\%) were from rural area and 108( 36\%) were from urban area.165 (55\%) were males and $135(45 \%)$ were females. Table 1 shows the education level and age wise distribution of the patients .Occupation analysis showed $138(46 \%)$ were farmers, $48(16 \%)$ were workers, $9(3 \%)$ were teachers, majority of females 96(32\%) were home makers .Source of knowledge was seen and majority $195(65 \%)$ found about TB through television,60 (20\%) through doctors , 30(10\%) through health care workers and $15(5 \%)$ through neighbours.

Table 1:- age wise distribution and educational status of study participants.

\begin{tabular}{|l|l|l|l|l|l|}
\hline Age group & number & $\%$ & Education & number & $\%$ \\
\hline$<29$ & 30 & 10 & Illiterate & 105 & 35 \\
\hline $30-39$ & 60 & 20 & $\begin{array}{l}\text { Primary } \\
\text { Education }\end{array}$ & 60 & 20 \\
\hline $40-49$ & 120 & 40 & Secondary education & 60 & 20 \\
\hline $50-59$ & 60 & 20 & $12^{\text {th }}$ pass & 45 & 15 \\
\hline$>60$ & 30 & 10 & Graduate & 30 & 10 \\
\hline Total & 300 & 100 & Total & 300 & 100 \\
\hline
\end{tabular}

234(78\%) knew that the disease is contagious and spread from person to person and 66(22\%) knew that it spread through coughing /sputum of infected person. Figure 1 shows knowledge of cause and table 2 shows knowledge about sputum disposal.

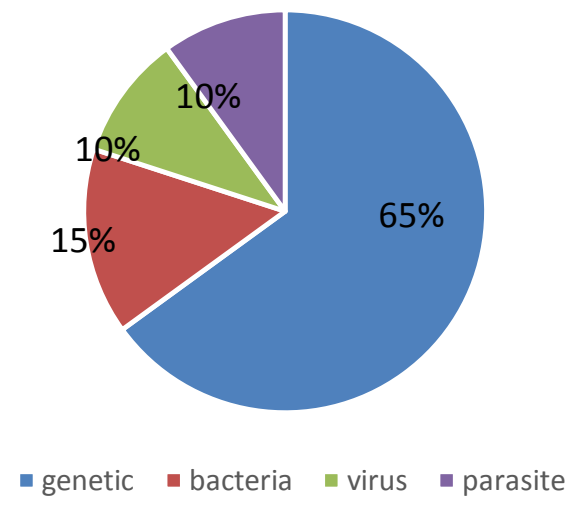

Figure 1:- Knowledge of cause of disease. 
Table 2:- Knowledge on sputum disposal.

\begin{tabular}{|l|l|l|}
\hline Method & Number & $\%$ \\
\hline Chemical treatment & 12 & 4 \\
\hline Inceneration & 18 & 6 \\
\hline Burial & 30 & 10 \\
\hline Anywhere & 900 & 30 \\
\hline Throwing with general waste & 150 & 50 \\
\hline Total & 300 & 100 \\
\hline
\end{tabular}

As age increased knowledge was poor. There was no association between gender and knowledge and the level of knowledge was better in the literate group than illiterate .Table 3,4,5.

Table 3:- Association between age and knowledge score.

\begin{tabular}{|l|l|l|}
\hline $\begin{array}{l}\text { Knowledge score } \\
\text { Age in years }\end{array}$ & good & poor \\
\hline$<29$ & & \\
\hline $30-39$ & 11 & 19 \\
\hline $40-49$ & 26 & 34 \\
\hline $50-59$ & 30 & 90 \\
\hline$>60$ & 20 & 40 \\
\hline Total & 6 & 24 \\
\cline { 1 - 2 } & 93 & 207 \\
\hline
\end{tabular}

Table 4:- Association between sex and knowledge score.

\begin{tabular}{|l|l|l|}
\hline Knowledge score & Good & Poor \\
& & \\
\hline Males & 55 & 110 \\
\hline Females & 40 & 95 \\
\hline
\end{tabular}

$\mathrm{P}$ value $=0.49$

Chi value $=0.47$

Table 5:- Association between education and knowledge score.

\begin{tabular}{|l|l|l|}
\hline Knowledge score education & Good & Poor \\
\hline Graduate & 20 & 10 \\
\hline $12^{\text {th }}$ pass & 15 & 30 \\
\hline Secondary & 20 & 40 \\
\hline Primary & 20 & 40 \\
\hline lliterate & 25 & 80 \\
\hline
\end{tabular}

Chi value $=19.28$

\section{Discussion:-}

In this study majority were males, similar findings were seen in a study by Deepu Changappa Cheriamane et al ${ }^{6}$. In a study by A. O. Hassan et al ${ }^{7}$, had higher female respondents than males who were $53 \%$. The study by A. O. Hassan et al ${ }^{7}$, saw correlation between gender and knowledge where males had greater knowledge but in this study no association was found. The study by Deepu Changappa Cheriamane et al ${ }^{6}$ had similar findings with the current study in age wise distribution. The study had $62 \%$ illiterates but the current study had only $35 \%$ illiterates. In the study by Deepu Changappa Cheriamane 6 et al ${ }^{6}$ had $18 \%$ who knew correct sputum disposal method in the current study the percentage was $28.5 \%$ which is higher. In a study by A. O. Hassan et al ${ }^{7}$, they found knowledge about tb to be $26.5 \%$ in our study it was found to be $22 \%$ still lower than the study. Similar lower numbers were found in a study by Tobin et al ${ }^{8}$. The study by Pieter Jacob Haasnoot, et al ${ }^{9}$, had $67 \%$ who had knowledge about tuberculosis. They found a positive correlation between education and knowledge, similar to current study. The study by Pieter Jacob Haasnoot, et al ${ }^{9}$, there were $32 \%$ people who thought tuberculosis was the punishment from god and in the current study there were $65 \%$ participants who thought it was genetic. The study by A. O. Hassan et al ${ }^{7}$, found association between education and knowledge similar to our current study. 


\section{Conclusion:-}

In this study most of them had poor knowledge of the disease spread and majority assumed the cause to be familial . Major source of knowledge was through television. Only few knew how to dispose sputum correctly . There was association between knowledge score and age and education. Literature indicates that health education programs for TB are well received and they improve TB control ${ }^{10,11,12}$. A high level of community awareness about the spread of TB, its prevention and positive perception towards TB and its management is crucial for the success of any control strategy. So, by increasing health education and utilizing television media to cover large population regarding awareness on the disease spread and prevention would be beneficial ${ }^{13}$.

\section{References:-}

1. Global TB Report, 2019. World Health Organization.

2. Mfinanga SG, Mørkve O, Kazwala RR. Tribal differences in perception of tuberculosis: a possible role in tuberculosis control in Arusha, Tanzania. Int J Tuberc Lung Dis. 2003;10:933-941.

3. Mangesho PE, Shayo E, Makunde WH. Community knowledge, attitudes and practices towards tuberculosis and its treatment in Mpwapwa district, central Tanzania. Tanzan Health Res Bull. 2007;9:38-43.

4. Barker RD, Millard FJ, Malatsi J. Traditional healers, treatment delay, performance status and death from TB in rural South Africa. Int J Tuberc Lung Dis. 2006;10:670-675. [PubMed]

5. Storla DG, Yimer S, Bjune GA. A systematic review of delay in the diagnosis and treatment of tuberculosis. BMC Public Health. 2008;14:8-15.

6. Cheriamane DC, Mohammed GJ, Verma BS, Kandal I, Hari DT, Nian SE, Asbin M. Knowledge of Cough Hygiene And Disposal of Sputum in Patients with Pulmonary Tuberculosis.

7. Hassan AO, Olukolade R, Ogbuji QC, Afolabi S, Okwuonye LC, Kusimo OC, Osho JA, Osinowo KA, Ladipo OA. Knowledge about Tuberculosis: A Precursor to Effective TB Control-Findings from a Follow-Up National KAP Study on Tuberculosis among Nigerians. Tuberculosis research and treatment. 2017;2017.

8. E. Tobin, P.-W. Okojie, and E. Isah, "Community knowledge and attitude to pulmonary tuberculosis in rural Edo state, Nigeria," Annals of African Medicine, vol. 12, no. 3, pp. 148-154, 2013

9. Haasnoot PJ, Boeting TE, Kuney MO, van Roosmalen J. Knowledge, attitudes, and practice of tuberculosis among Maasai in Simanjiro District, Tanzania. The American journal of tropical medicine and hygiene. 2010 Oct 5;83(4):902-5.

10. Kayombo EJ, Uiso FC, Mbwambo ZH. Experience of initiating collaboration of traditional healers in managing HIV and AIDS in Tanzania. J Ethnobiol Ethnomed. 2007;26:3-6. [PMC free article] [PubMed]

11. Colvin M, Gumede L, Grimwade K. Contribution of traditional healers to a rural tuberculosis control program in Hlabisa, South Africa. Int J Tuberc Lung Dis. 2003;7:86-91. [PubMed]

12. Gai R, Xu L. The role of village doctors on tuberculosis control and the DOTS strategy in Shandong Province, China. Biosci Trends. 2008;2:181-186

13. D. Okuonghae and S. Omosigho, "Determinants of tuberculosis case detection in. 